\title{
From Theodicy To The Idea Of God
}

\author{
Igor Zaitcev*
}

\begin{abstract}
In the spectrum of possible objections to theodicy, we distinguish two of them: doubts about the morality of a successful theodicy and argument of skeptical theism against the possibility of a successful theodicy (because our cognitive ability is limited, so it is doubtful our ability to understand what God wants to make good in the world and how the existing evil due to their offspring). Experience of undeserved suffering of Job, in conjunction with the answer Yahweh gives us the opportunity for a productive dialogue with the specified points of view. In the theodicy of book of Job difference arises between the name of God and God. The name of God indicates the essential definition of God, the name refers to a specific service to Him. Job searchs for the meaning of service, he sends God a subpoena, he actually wants certainty, or name what would precede him; in response he gets antecedence as antecedence itself. In some ways Good (and Justice) is the name of God, but He does not match the name completely; the name and God are distinguished. In this sense we can talk about an amoral God. The result of theodicy is more accurate concept of God. We come to the other idea of God than the one which began theodicy. Accordingly, an aspect of moral doubtfulness of theodicy removed completely: goal of theodicy is not an excuse of evil, but the knowledge of God; cognition of God can not be considered immoral. The thesis of skeptical theism is more complicated. I must admit: our understanding of theodicy does not allow to attack the skeptical point directly, but weakens the point and allows you to perform a outweigh condition.
\end{abstract}

Key words: theodicy, sceptical theism, morality, amorality.

\section{Contents}

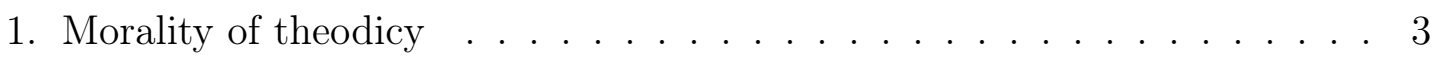

2. Skeptical of the theodicy . . . . . . . . . . . . . . . 4

3. Book of Job . . . . . . . . . . . . . . . . . . . . 4

4. Some consequences . . . . . . . . . . . . . . . . . . . . . . 8

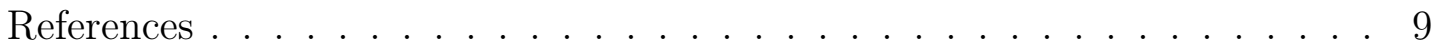

*Associate professor; Saint-Petersburg State University of Aerospace Instrumentation; zaytsev@einai.ru. 
Nowadays according to A. Plantinga [3] in the problem of evil within philosophical theology is accepted to distinguish the two questions:

1. a demonstration of how evil is possible, in other words a study of logical compatibility the existence of God and evil;

2. question about the positive place of evil in the universe, the search for the true explanation of evil on condition the existence of God.

Only for a second question was fixed value of theodicy in the narrow sense of the word and it is in this sense I use it.

Thus, what it means to build a theodicy? Apparently it means a demonstration of how evil is an inevitable condition or a byproduct of existence of the world as a whole (or conditions and / or products of benefits greater than the evil inflicted things). With all the attractiveness the positive solution of the problem of evil, the solution meets several fundamental objections. Recent objections of this sort are as follows:

- successful theodicy is questionable from a moral point of view: to explain evil is to justify its presence in the world, which decreases our determination to resist evil and generally speaking morally unacceptable;

- implementation of theodicy suggests our ability to learn the benefits that God wants to make in the world and how the existing evil associated with offspring benefits, but our ability to learn these benefits is questionable (point of view of skeptical theism).

We can not say that these difficulties make convincing theodicy completely impossible, but they pose difficult questions in front of those who expect it to reach. I do not claim to provide an exhaustive removal of these difficulties, ${ }^{1}$ I believe to point to way to overcome them.

In section 1 I will follow up a few doubts in the moral justification of theodicy. This part is particularly important in the context of Russian religious philosophy because of the wide dissemination similar point of view. Section 2 is devoted to explicating of skeptical theism position. This skepticism has not yet entered into our discussions, but all the more important to fill this gap. Section 3 is devoted to a brief analysis of the book of Job. Literature on the interpretation of this one of the most mysterious books of the Bible, truly great, even if we restrict ourselves to what published in Russian. We do not aim to describe and compare at least only the most popular interpretation, we only offer a certain reading of this book ${ }^{2}$ to challenge the position shown in the sections 1 and 2. Our point of view is reflected in the section 4 .

\footnotetext{
${ }^{1} \mathrm{~A}$ more complete disclosure of the problem of theodicy requires, inter alia, a detailed consideration of questions: what is evil in the general sense of the word?, what is the justification for the suffering, what is sin? (and how it relates with evil and suffering) and many others. For my purposes it is sufficient to accept the judgment: innocent suffering is evil.

${ }^{2}$ The guide line for me is made by O. M. Nogovitsyn's interpretation [2, 87-93].
} 


\section{Morality of theodicy}

Objection indicates possible logical consequences from the exercise theodicy. Indeed, suppose that we have been able to build a convincing theodicy. This means that we have shown exactly how evil is built in the world on the rights of its a positive element of the world. Thus we have given evil as if it was needed evil.

On the one hand, the inevitable presence of evil in this life may serve as our consolation. What can not be removed from our life is absurd to grumble for the presence of. Take a simple example. I slipped and fell, eventually the force of gravity was the cause of my fall; it caused me some evil (I feel pain), but I understand the objective nature of physical law, and the understanding makes my feelings about the incident easier.

On the other hand, giving the evil the status of the law of nature, we change the moral evaluation of events. If the presence of evil in the world is completely analogous to the presence of the law of gravitation, then we should stop fighting against evil. More precisely, we should not try to overcome evil we should interact extensively with evil. We should strive to own objectives consistent with the law of evil in the world, just as we are acting consistent with the law of gravity. In essencewe have to use evil in their own interests, which seems morally dubious.

This view is widely represented in the works of Russian Orthodox theologians and religious thinkers in the early XX century and today. Here's an example: Semyon Frank developed the thesis that because of our false mental habits «to explain is to understand» and «to understand is to forgive». So, he said, I do not intend to forgive evil, and therefore will not come up, hence, as the reasons why it happened. There is no reasons of evil, it should not be and to nothing to build such scheme of the universe, which is rational and reasoned would show the necessity of evil and provided him with a cozy place. Famous contemporary the publicist and the theologian Andrew Kuraev argues similarly:

It is a choice, ${ }^{3}$ and therefore freedom. Explained freedom is no longer a freedom. If the logically necessary path found, leading to precisely this free act, then this act was not free, but was provoked by their causes. $\langle\ldots\rangle$ The point is that not only philosophically impossible but also morally unacceptable to describe the origin of evil.

According to this objection theodicy is conceals the moral significance of evil and limit our determination to confront it. Moreover, when we turn to the problem of evil, then we are in a paradoxical situation. To understand what is evil, we should at least mentally to join evil. But Scripture tells us otherwise: Abhor that which is evil (Rom. 12: 9). This paradox suggests that the problem of evil is not a purely theoretical. Turning to the problem of evil, we are especially clear recognize that understanding requires involvement in what we want to understand. Evil is not a neutral object. Understanding evil in itself is a spiritual problem.

\footnotetext{
${ }^{3}$ Kuraev has in mind primarily, but not exclusively, evil in the form of action.
} 


\section{Skeptical of the theodicy}

Skeptical theism raises the following thesis [1]: if we want to explain the presence of evil in the world, we should be able to know what God wants to make good in the world and how existing evils associated with generation of good. But then we must recognize theodicy almost unattainable on two grounds.

Firstly, God is infinite in His goodness and omniscience, whereas we clearly recognize the limitations of the mental and moral human abilities. From incommensurability between abilities of God and human abilities is easy to assume that there is a certain amount of of benefits, we do not known. Therefore we can not expect to demonstrate the presence of substantial grounds of God for admission of evil, because our mind can not learn the benefits for which allowed evil.

Secondly, even if we know all the goods, then our ability to establish the exact cause-and-effect relationship between good and evil looks doubtful. Since man does not possess omniscience, he might not understand what evil events are prerequisites for good events, both events distant from each other (and from us) in time and space.

These arguments are directed by two points. Both things are problematic: our ability to learn all the benefits provided by God, and our ability to establish a causal link between a specific evil and the particular good.

It should be noted this theism distancing from atheism. Skeptical theism does not require us rejection of theodicy. The skepticism may be directed against atheists who argue the non-existence of God based on the problem of evil. How atheists respond to skepticism is rather curious, but is beyond our consideration. On our part, we admit the validity of this skepticism and hope to indicate our position on possible answer to the skeptics.

\section{Book of Job}

The suffering of any particular person is always a chance that it is reasonable to to explain suffering as a punishment for sins. In this case, theodicy is as follows: God wants man good and punishes him for his sins, to induce a person not to sin. Leaving aside the question of the effectiveness of such a pedagogy, we merely note that, in any case, God certainly has the moral right to punish the defaulting person from His commandments. But we are interested in a more complex case, which calls into question the moral right to punish. Let us turn to one of the oldest theodicy in the book of Job. The question of the justice of God is placed extremely acute: the righteous Job afflict such disasters as there is no doubt that the all these misfortunes are deliberate acts of God and Job wants to know «why? what for?». ${ }^{4}$

\footnotetext{
${ }^{4} \mathrm{I}$ omit discussion of two different stages testing Job: first one takes away all the property that does not rise to any question of Job to God (Job's response to the first wave of disasters lies in perhaps the most quoted passage: «And said, Naked came I out of my mother's womb, and naked shall I return thither: the LORD gave, and the LORD hath taken away; blessed be the name of the LORD» Job 1: 21); and the main events unfold only after the defeat of leprosy. I recognize the importance of this distinction stages, but it is not essential for my purposes.
} 
Job's question is valid. Because the events in the book unfolds as follows: first God recognizes Job's righteousness, ${ }^{5}$ then He takes issue Satan Is righteous a righteous man? ${ }^{6}$ This excludes a pedagogical explanation of evil caused to Job.

The difficulty of the Job is that he is clearly aware the injustice of all disasters. To clarify this fact the author of the poem engages him in conversation with friends. They try to console Job giving reason for the validity of his suffering. Rhetorically their speeches are very diverse, but the logical basis of their position is quite simple:

1. God is just and sends disaster as a punishment for sins

2. disaster brought upon you explicitly

3. therefore you are a sinner and must repent.

Compassionate to him friends convince him to justice punishment, and partly we can understand them, you can not see in Job good man because of the suffering, but Job stands on its: no guilt in me. It is clear that Job deprived of the opportunity to hope for a reward after death. While the Jews had not yet had concept of full existence after death. Therefore nobody could hope to obtain compensation after death for the injustices of life. Staying in such situation is intolerable and Job despairs, ${ }^{7}$ he is making a riot, he sends God subpoena.

God speaks to Job, and does not respond to his complaints and questions, but the very fact of epiphany eliminates riot. Generally speaking speech of God produces a very strange impression. If He does not understand what the conversation was about before He intervened. Job and his friends ask what is good and evil, why blessed unjust and killed innocent, - and God with childlike enthusiasm describes to them order of universal life, boasting his power and knowledge of each insignificant trivia. Job demanded an explanation, God did not give it him, but somehow He removes Job's demands. Final of the book can be understood as a description of the mystical experience, which removes the need for a theodicy that is tantamount to accept the impossibility of rational theodicy as such. My position is different. There is rational side in the experience of what happened.

\footnotetext{
${ }^{5}$ «And the LORD said unto Satan, Hast thou considered my servant Job, that there is none like him in the earth, a perfect and an upright man, one that feareth God, and escheweth evil?» (Job 1: 8).

${ }^{6}$ Satan says literally follows: «Then Satan answered the LORD, and said, Doth Job fear God for nought? Hast not thou made an hedge about him, and about his house, and about all that he hath on every side? thou hast blessed the work of his hands, and his substance is increased in the land. But put forth thine hand now, and touch all that he hath, and he will curse thee to thy face» (Job 1: 9-11).

${ }^{7}$ However, there are different kinds of despair. Job's wife despaired in the face of all these misfortunes too. «Then said his wife unto him, Dost thou still retain thine integrity? curse God, and die» (Job 2: 9). We understand the meaning of her advice in the context of the intolerable situation of Job. After death you do expect nothing, but at least you will interrupt the unfair suffering. Job refuses the offer of his wife and his refusal clearly indicate that it grieveth him not because of the magnitude of misfortunes. What he does not understand the reason for all of this, that is hard. Job's riot is that he does not ask, but he demands an explanation from God.
} 
Where a pagan begins any religious service? He learns the name of God. Name is not some theological abstraction, this thing is extremely practical: to learn the name of god is to know in what form someone should serve this god. Every pagan god accepts a very specific ministry. Man serves Ares in a way practicing martial arts; Ares can not be served by trade, the trader serves Hermes. Famous Moses' question about God's name should be understood in this context. ${ }^{8}$ Moses wants to know the name not from abstract motives, he asks God «in what particular form you accept our ministry?» And God does not give a direct answer to the question, He does not indicate any form of ministry. His evasiveness can be understood in two ways: there is no form of worship this God (but then with His hand is completely pointless to send a messenger to the people), or there are a lot of forms, and none of them is highlighted.

Since any form of serving God (pagan and The One) is fixed to a set of rules, commandments (what is allowed and what is forbidden), so far about the man serving God, it remains unclear whether he understands how does he differ in his ministry from a pagan one. In fact you can understand the Torah of Israel as a very large and complex name of God, which is not fundamentally different from the name of any pagan god.

The name of God not only determines the form of service, but it gives the description language for the world in general. Man serving Hermes describes the world by language of commerce - he can understand anything and he may designate the price of everything. Beauty, purity, artwork - all have its price. Minister of Ares understands even love as a kind of struggle, as the battle with the enemy. And so forth.

Job's friends, if I may say so, serve «justice»; «justice» is a name of god. That is why they so persistently, over and over again, trying to explain what is happening with Job in terms of justice, punishment and sin. They see the world in such a way, and the resistance of Job, his disagreement with their descriptions of Job's disasters what they perceive as an attempt to destroy their world and denial of God. At the end of the book God condemns Job's friends quite clearly and unambiguously. ${ }^{9}$ They believed «justice» is the name of God and they were wrong. God is saying to to them «My name is Jehovah (I am that I am), but I am not limited by my specific name».

On the other hand, does justice at all have nothing to do with God? Such a statement is absurd too. Justice, of course, is the name of God, but He is not limited by it. Pagan god is identical with his name. This allows someone who serves perfectly such a god to become equal with the god. Antique hero (eg.

\footnotetext{
${ }^{8}$ «And Moses said unto God, Behold, when I come unto the children of Israel, and shall say unto them, The God of your fathers hath sent me unto you; and they shall say to me, What is his name? what shall I say unto them? And God said unto Moses, I AM THAT I AM» (Ex. 3: $13-14)$.

${ }^{9}$ «LORD said to Eliphaz the Temanite, My wrath is kindled against thee, and against thy two friends: for ye have not spoken of me the thing that is right, as my servant Job hath. Therefore take unto you now seven bullocks and seven rams, and go to my servant Job, and offer up for yourselves a burnt offering; and my servant Job shall pray for you: for him will I accept: lest I deal with you after your folly, in that ye have not spoken of me the thing which is right, like my servant Job »(Job 42: 7-8).
} 
Hippolytus from Euripides' tragedy) is not just the best servant of the goddess, he communicates with the goddess as an equal (Hippolytus is not just in the retinue of Artemis, he hunts with her equally, shoulder to shoulder). One God does not coincide with his name (names) and thus gives more freedom to his servants. To serve Artemis is to be perfect hunter and to keep his virginity. Aphrodite ministry is the ministry of love and thereby excludes Artemis ministry. Whereas if God is different from His names, you can serve Him in many different ways: he can be served by love, by justice, by celibacy - all forms of worship addressed to the same God.

One more thing about paganism. Learning god in his name, a pagan learns at the same time two quite different things: form of serving god and the fact that god is revealed to him as something preceding. Man can only begin to serve god in the way he joins the service of god as to what it was before the person. That is why even the creation of a new cult looks like the restoration of historical tradition. For example, we know virtually nothing about Slavic paganism, and so those people who today are reviving these cults have to create it again. But the creators of the new cult themselves perceive their actions just as the restoration of the former preceding.

One God holds the distance between himself and his name in a way that only indicates his preceding. This is the sense of God's speech to Job. When God asks Job «Where wast thou when I laid the foundations of the earth?» (Job 38: 4), He does not want to intimidate him and He says it does not in the sense of «how dare you ask me questions». No, He simply points to His preceding as such. In some sense we can say that two God's long speeches in the final of the book carry exactly the same message that the short answer to Moses «I am that I am». In this way, God explains to Job distance between Himself and His name.

What was Job looking for in his rebellion? He was looking for explanation for his misery; his troubles did not fit into any picture of the world and it was certainly only to increase his suffering. But what would mean a God's direct answer? Obviously, such an answer would have presented a new picture of the world to Job in which all his troubles would have been inscribed in a certain picture of the world as regular part. In other words, thereby God would provide new language of description of the world to Job. And what does it mean in its turn? Only that God would open to Job his another name (as we remember, the name of God determines the form of ministry and the descriptive language of the world). Instead, God teaches Job another thing, He tells him the truth about Himself: God does not coincide with his name.

Now we can formulate two major consequences from consideration of theodicy in the Book of Job. Firstly. What does it means that God does not coincide with His name «justice, morality»? At least, this means that the category of justice and morality do not apply to God himself; it means that God is amoral. Whereas the starting point for the thesis of theodicy was God's justice (we started from the justice of God when we put the problem of evil). This does not mean falsity of our constructions, our knowledge of God just changed. We have gone from a simple point of view to the more complex one, we refined the idea of God. 
Secondly. We clarify the meaning of theodicy. The purpose of theodicy is not so much an excuse the presence of evil in the world as a justification of God, to be precise - the purpose is cognition of God. We know Him better now than before the theodicy. How does this affect our position on the objections against theodicy from sections 1 and 2 we will discuss in section 4 .

\section{Some consequences}

The result of new understanding of theodicy is new idea of God, which is different from that implied by raising the question of evil. A few roughly, we can say that we started with the kataphatic concept of God, and came to almost apophatic concept of God.

New concept has practical value. For such a split between name of pagan god and god himself would destroy the very foundations of righteousness (we remember that the concreteness of pagan god ministry, specified by god's name, creats a real opportunity to be righteous). For the believer in One God that split means the opposite - the foundation of virtue. Now virtue can not be revealed an active way, because over all activities (fulfillment of the commandments and other religious rules) essentially remains unclear whether it approves the case itself (action of the righteous man) or the name of God. In paganism action of the righteous man and the name of God are the same, but in Scripture it is not.

God send misfortunes to destroy Job's every opportunity to be and look like a righteous man. If Job was a pagan, these misfortune would have destroyed his very virtues irretrievably, but Job was not a pagan and evil helps him to discover the true condition of righteousness. Now a righteous man does not draws on meaning and reward for his righteousness in the righteous action (in keeping the commandments, and so on), but he is aware of preceding to him what he should do. Thus, the righteous is not enough to fulfill the commandments, he should yet be aware of (and hold the consciousness) differences name of God from God Himself. In Christianity, this requirement accepts the special form: a righteous man, keep understanding of all the goodness of his service to God, nevertheless is clearly aware the depth of his sinfulness. A righteous man admits his sinfulness what is irremovable consequence of the retention differences between the name of God, which he embodies in his ministry, and God himself. The depth of this difference is reflected in consciousness of his sinfulness.

Doubts about the morality of theodicy based on the assumption that we believe evil as a kind of necessary part of the world. In fact, as we see sense of theodicy a slightly different: theodicy does not justify evil in such sense. Theodicy in no way proves the necessity or inevitability of evil, it leads to cognition of God. I believe cognition of God is not in doubt from a moral standpoint. Therefore analysis of theodicy of Job completely removes these doubts.

Case of skeptical theism is more complex. This position is based on the dubiousness of our abilities to the knowledge of the benefits that are the consequence of evil in the world. To overcome these doubts need to specify some good, comprehended by us as a result of evil. I believe in Job's case such good we are able to specify: it is cognition of God. We also grasp the metaphysical condition of 
righteousness. It is not clear until the end for me whether the cognition of God and condition of righteousness are good in terms of skeptical theism. Anyway, I hypothesize: cognition of God and condition of righteousness are good and furthermore, I believe that such good are sufficiently outweighs the existence of evil. ${ }^{10}$

\section{References}

[1] Michael Bergmann. Skeptical Theism and Rowe's New Evidential Argument from Evil. Noûs, 35(2):278-296, 2001.

[2] Oleg Mikhailovich Nogovitsyn. Poetika russkoi prozy [Poetics of Russian prose]. VRFSh, Saint Petersburg, 1999.

[3] Alvin Plantinga. God, Freedom and Evil. Harper \& Row, New York, 2002.

[4] Richard Swinburne. Providence and the Problem of Evil. Oxford University Press, 1998.

\footnotetext{
${ }^{10}$ I refer to one of the criteria for success of theodicy by Swinburne [4, 23].
} 